\title{
Tourism and Disasters: Impact of Disaster Events on Tourism Development in Indonesia 1998-2016 and Structural Approach Policy Responses
}

\author{
Erda Rindrasih ${ }^{(D)}$, Patrick Witte, Tejo Spit, Annelies Zoomers \\ Department of Human Geography and Spatial Planning, Faculty of Geosciences, Utrecht University, Utrecht, The Netherlands \\ Email: E.Rindrasih@uu.nl, erdarindrasih@gmail.com
}

How to cite this paper: Rindrasih, E., Witte, P., Spit, T. and Zoomers, A. (2019) Tourism and Disasters: Impact of Disaster Events on Tourism Development in Indonesia 1998-2016 and Structural Approach Policy Responses. Journal of Service Science and Management, 12, 93-115. https://doi.org/10.4236/jssm.2019.122006

Received: January 17, 2019

Accepted: January 29, 2019

Published: February 1, 2019

Copyright $\odot 2019$ by author(s) and Scientific Research Publishing Inc. This work is licensed under the Creative Commons Attribution International License (CC BY 4.0).

http://creativecommons.org/licenses/by/4.0/

(c) (i) Open Access

\begin{abstract}
Over the last two decades, disaster events have affected tourist destinations in many countries around the world. Although disasters have attracted considerable attention in academia, little attention has been paid to the impacts of recurring disasters on the multiyear performance of the tourism industry in a specific country. This paper discusses the relationship between the performance of the tourism industry and disaster events and examines the spillover effects of disasters on the tourism sector in Indonesia. It also highlights the Indonesian policy responses in tourism following multiple disasters. The paper analyses the multiyear (1998-2016) performance of the tourism industry using the variables number of inbound tourists, national/regional income from tourism, and hotel room occupancy rates. Secondary data were collected from several sources, including legal documents, Indonesia's tourism statistics, media outlets and newspapers articles. The results show that during the past 18 years, disasters have affected the performance of the tourism industry differently in terms of the scale of destruction, the location of disasters and the type of disasters (human vs. nature induced). The spillover effect between provinces has also been captured from the data. Overall, this paper argues that in dealing with multiple disasters over long periods of time, the continuation of regular tourism activities needs a structural approach in terms of policy responses.
\end{abstract}

\section{Keywords}

Impact, Disaster, Tourism, Spillover, Structural Approach

\section{Introduction}

Over the last two decades, many disasters have affected tourist destinations 
around the world. Events such as terrorist attacks and Hurricane Katrina in the USA, the severe acute respiratory syndrome (SARS) epidemic in Asian countries, the outbreak of foot and mouth disease in the UK, and the Indian Ocean tsunami had an extensive adverse impact on international tourism [1]. Since the tourism industry is an economic activity that is mostly influenced by the image of the destination, negative images of a destination affect the performance of the tourism industry. Despite such disasters, the tourism industry is continuing to grow both locally and globally and is a major source of economic development in many countries.

Some scholars view tourism from a complex systems approach [2]. To study the impact of disaster on the performance of the tourism industry, it is essential to define and conceptualize the interactions in the tourism system [2]. Moreover, it is important to examine the effects of each disaster event on the performance of the tourism industry to better explore the relationship between disasters and tourism. According to Faulkner [3] (p. 136): “... relatively little systematic research has been carried out on disaster phenomena in tourism, the impacts of such events on the tourism industry and the responses of industry and relevant government agencies to cope with these impacts”. In other words, the relation between the nature of disasters (both single and recurring events) and the long-term impacts on the performance of the tourism industry could benefit from more structural and systematic analyses and subsequent policy responses.

Research on the impact of disasters on the performance of the tourism industry is relatively new. Although some important studies have shown the impacts of disasters on tourism, the studies were often based on single event impacts, relatively small areas and single destinations. For instance, hurricanes (e.g. Higgins [4]), flooding and tsunamis (e.g. Calgaro \& Lloyd [5]; Cheung \& Law [6]), earthquakes (e.g. Huang \& Min [7]), volcanic eruptions (e.g. Carlino et al. [8]) and bushfires (e.g. Armstrong \& Ritchie [9]). In addition, some studies focused on non-natural disaster events, for example, foot and mouth disease in the UK (e.g. Rodway-Dyer \& Shaw [10]) or SARS in Asia (e.g. Au et al. [11]).

This aim of the present research was to understand the secondary impact of several disaster events in Indonesia on the performance of the tourism industry in 1998-2016. "Secondary" impact refers to consequences that "extend beyond the people directly affected by the original hazard event or report" [12]. This opens up the possibility to understand the impact of single events in one particular province or district on the performance of the tourism industry of a whole country (bigger subsystem). Secondary impact can also be understood as both the positive and the negative spillover effects on other regions. Thus, the following research questions were addressed: 1) what is the impact of long-term multi-disaster events on the performance of the tourism industry in Indonesia, and 2) how does the government deal with this? Furthermore, this research would like to contribute to the knowledge on the tourism development in relation to disaster study. 
The following section discusses the conceptual framework on disasters in a complex systems understanding of tourism and related spillover effects. Section 3 explains the methodology of the research. Section 4 presents the results of the research, which include an inventory of the large-scale disaster events in Indonesia from 1998 to 2016 and a discussion of the impacts of these disaster events on the performance of the tourism industry, the spillover effects and the government's responses. Section 5 discusses the findings. Finally, Section 6 presents the conclusions and a recommendation for further research.

\section{Literature Review: Complex System and Spillover Effect}

\subsection{Disasters in a Complex Systems Understanding of Tourism}

Since tourism is often affected by external events beyond the control of individuals or destinations, many scholars consider tourism an open system. However, the majority of tourism crisis management frameworks consist of an orderly, linear sequence of steps. Therefore, the impact of crises has not been subject to an in-depth examination that starts by acknowledging the tourism industry as a complex system [2] [13] [14]. A simple, linear relationship and causal chain have limited ability to explain complex phenomena in physical and social sciences (including tourism), whereas a systems thinking approach can be applied to understand the complexity of tourism [15].

A complex systems understanding of tourism has been claimed to be a better approach to answering questions about the components, the type of interaction and the type of system [16]. This view is also discernible in later studies (e.g. Baggio [17]; Haugland et al. [18]), where authors agree that each tourist destination has different types of systems, actors, characteristics and behaviours. Thus, in understanding the relationship between tourism destinations and disaster events, a complex systems understanding could be seen as apposite to describe the social, economic and environmental dynamics of the tourism industry.

In the literature, the words "crisis" and "disaster" have been often used interchangeably. Faulkner [3] defines a crisis as a self-inflicted event caused by problems, such as inept management structures and practices or a failure to adapt to changes. A disaster has a different meaning: it refers to a situation in which an enterprise (or a group of enterprises) is confronted with sudden unpredictable and catastrophic changes over which it has little control [3].

Many authors have attempted to understand crises by examining their characteristics, lifecycles, anatomies, complexities and natures. Beeton [19] defines crises based on the level of severity, while Coombs [20] defines the range of crises in organizations based on scale, namely small-scale organizational issues (e.g. staff illness), malevolence and large-scale issues (e.g. earthquakes, floods, terrorist incidents and fires). Parson [21] suggests three types of crises based on the nature of their occurrence: immediate crises, where there is little or no warning and organizations are unable to research the problem or prepare a plan before 
the crisis occurs; emerging crises, which are slow to develop and therefore organizational intervention may be able avert them; and sustained crises, which may last for weeks, months or even years. These types of crises have similarities in the need for intervention to stimulate recovery and the drive to implement some structural changes after recovery.

Disasters may impact the tourism subsystem differently, which can be measured based on the scale of events and the capability of the system to deal with the events depending on the nature of the crises. This means that there is an interconnection between tourism subsystems in which one subsystem will be affected by disruptions in other subsystems. In tourism, the secondary impact of disaster on the industry has mostly been measured using the spillover effect on other regions and the impact after some period of time, rather than the direct impacts.

\subsection{Spillover Effect of Disasters on the Tourism Industry}

Spillover effects are mostly discussed in economic terms that explain both positive and negative externalities resulting from economic activity or processes that affect any element not directly associated with the activity [22]. In tourism studies, spillover effects are translated into the indirect or intentional effect of tourism flows on other regions that positively or negatively impact the performance of other regions. Some non-tourism scholars have also highlighted the spillover effects by using econometric analysis (e.g. Drakos and Kutan [23]; Goorochurn and Hanley [24]; Neumayer [25]). Yang and Wong [22] argue that some interpretations of spillover effects in previous studies are vague and that there is no consensus on the definition of such effects.

The majority of studies on crises and disasters in the tourism industry focus on a single crisis or disaster in one geographic location [26], and by doing so overlook the spillover effect [27]. Nevertheless, Ritchie et al. [27] (p. 15) state: "Data at this level, i.e. a particular crisis in one geographical location, may mask micro differences and may not provide any insights into the spillover effects or redistribution of demand". From a geographical perspective, spillover effects can be regarded as a spatial interaction among destinations in terms of tourism flows. However, some studies (e.g. Gil-Pareja, Llorca-Vivero and Martinez-Serrano [28]; Khadaroo and Seetanah [29]) focus only on a spatial interaction model between origin and destination without considering the neighbouring regions. This paper highlights the spillover effects of a disaster event in one province on other provinces to cover the geographical perspective of complex systems in the tourism industry. A hypothesis, variables and analysis in specific case study area were developed to meet the aims of the paper.

\section{Methods}

\subsection{Variable and Analysis}

Following a complex systems approach (e.g. Scott and Laws [2]), disaster events in a tourist destination are assumed to impact the performance of the tourism 
industry in that country. The present research applied three statistical data as variables to analyse the performance of the tourism industry: number of inbound tourists arrivals, hotel occupancy rate and income from tourism. Number of inbound tourists arrivals and hotel occupancy rate reflect the tourism demand [30]. The hotel occupancy rate was applied as a variable in this research to measure the year on year growth or decline in overnight stays in all types of accommodation [31]. The indicator "income from tourism" was used to get a better overview of the performance of Indonesian tourism. This indicator has also been used to measure competitiveness in tourism by World Economic Forum [32]. Table 1 presents the variables of the assessment. They are either increasing or decreasing, and their dynamic was assessed to establish the tendency and possible relation with the events of the disaster at the time of analysis.

In addition to assessing the impact of disaster events on the performance of Indonesia's tourism industry, the present research also examined the government's general policy towards the problems that may arise due to disasters. The policy data were gathered by examining published government documents.

\subsection{Case Study and Data Gathering}

Although there are good practices of using primary data in tourism research, secondary data are also widely used [27]. In secondary data analysis, the researcher has not participated in the planning of the data collection or the actual collecting. Secondary data are usually gathered from published materials, such as statistical data, journal articles, websites, records or reports [33]. Saunders et al. [34] state that secondary data can be regarded as a suitable data source for tourism research because it is considered reliable and valid and can be used to address the research question.

Three government-based boards-namely the National Disaster Management Agency of Indonesia, Statistics Indonesia Board, and the Ministry of Tourism-provided the secondary statistics data for this analysis. The disaster events data were collected from the National Disaster Management Agency of Indonesia and various news media. Statistics Indonesia Board also provided data on inbound tourist arrivals and the hotel occupancy rate from a regular survey. Hence, the data on income from tourism were gathered from the tourism statistics of the

Table 1. Variables for assessment framework of the tourism industry performance.

\begin{tabular}{cl}
\hline Variables of analysis & \multicolumn{1}{c}{ Explanation } \\
\hline $\begin{array}{c}\text { Number of foreign } \\
\text { tourists (inbound } \\
\text { tourists arrivals) }\end{array}$ & $\begin{array}{l}\text { The number of visitors from other countries entering Indonesia by air, water } \\
\text { and land. Indonesia has 93 gateways: } 65 \text { harbours, } 24 \text { international airports } \\
\text { and } 4 \text { border crossings. The major airports are Soekarno-Hatta (Jakarta), } \\
\text { Ngurah Rai (Bali), Polonia (Medan) and Sekupang (Batam). }\end{array}$ \\
Hotel occupancy rate & $\begin{array}{l}\text { The average percentage of occupancy for hotels with a star rating and hotels } \\
\text { without a star rating }\end{array}$ \\
Income from tourism & The total amount of money earned from tourism activities
\end{tabular}

Source: Author's framework. 
Ministry of Tourism. Inbound tourists arrivals data are gathered from arrival and departure cards (A/D cards) at the Immigration General Directorate. In addition, the hotel room occupancy rate was formulated in the form of a comparison between the number of rooms occupied by tourists and the total number of available hotel rooms. The accommodation statistics were gathered from the Tourism Statistics sub-directorate of Statistics Indonesia. Data were obtained from a reliable resource database that allows for an objective assessment of the performance of the tourism industry, because all Indonesian provinces use the standard methods. Due to the availability of the secondary, the time frame of the data was 1998-2016.

\section{Crisis Events in Indonesia}

Over the last two decades, Indonesia has experienced a lot of disasters and crises that threatened economic performance, including tourism (Table 2). The 1997 economic crisis led to the downfall of the Suharto regime-the longest presidential regime in Indonesian history (30 years) - and the start of the political transformation era. The shift in the political regime also changed the way Indonesia manages the country, especially regarding the tourism industry and disaster management. The most devastating natural disaster the 2004 Indian Ocean tsunami-challenged the economic situation, which had almost been restored in the post-political transition from centralized to decentralized government. The following paragraphs describe some of the most significant crises and disaster events that have happened in Indonesia over the past two decades. They are categorized into natural disaster and non-natural (i.e. human-induced) disaster.

\subsection{Natural Disasters}

Indonesia is highly prone to natural disasters because it is located in "the ring of fire"-an area of intense seismic and volcanic activity stretching from the edge of the Pacific Plate and the smaller plates (e.g. the Philippine Sea Plate) to the Cocos and Nazca Plates that line the edge of the Pacific Ocean. In recent years, Indonesia has been subject to numerous natural disasters, which are increasing in terms of both frequency and number of victims. Several of the biggest disasters

Table 2. Some disaster events in Indonesia.

\begin{tabular}{cl}
\hline & India Ocean tsunami, Aceh (2004) \\
& Yogyakarta earthquake (2006) \\
& Merapi eruption, Central Java and Yogyakarta (2010) \\
Natural disaster & Kelud eruption (2014) \\
& Mentawai and Nias earthquake and tsunami (2010) \\
& Jakarta floods (2013) \\
& Terrorist attack, Bali (2002 and 2005) \\
& SARS outbreak (2003) \\
Non-natural disaster & Political unrest/separatist movement and rebellion \\
& Transport incidents \\
\hline
\end{tabular}

Source: Authors 
reported by the Disaster Management Agency of Indonesia include the following.

\section{1) India Ocean tsunami, Aceh (2004)}

This tsunami is recorded as the most devastating disaster to befall Indonesia in over 100 years. A magnitude 9.0 earthquake was recorded by the Pacific Tsunami Warning Center and a magnitude 9.1 earthquake was registered by the United Stated Geological Survey. The epicentre of the earthquake was $30 \mathrm{~km}$ deep in the Indian Ocean, about $160 \mathrm{~km}$ north of Simeulue Island. After the tsunami, the Indonesian Minister of Health reported that 220,000 Indonesians had been killed. The tsunami devastated Aceh Province, the west coasts of Malaysia and Thailand, the east coasts of India and Sri Lanka, and the east coast of Africa. Among the victims were 9000 foreign visitors, mostly Europeans.

\section{2) Yogyakarta earthquake (2006)}

A 6.2 magnitude earthquake hit Yogyakarta in May 2006, killing more than 6324 people. The earthquake also struck the regencies of Klaten, Banyumas, Semarang and Blora in the neighbouring province of Central Java. Major infrastructures and facilities were affected, including Adi Sutjipto International Airport, which had to be closed because of a crack in the runway and a broken-down communication system. The earthquake was associated with a $2.61 \%$ fall in the number of foreign visitors to Indonesia in the following year. The occupancy rate of star rated hotels in Yogyakarta also dropped.

\section{3) Merapi eruption in Central Java and Yogyakarta (2010)}

In November 2010, 43 volcanic eruptions from Merapi were recorded in what was said to be the largest and most powerful series of eruptions ever recorded. Ashes fell as far as $13 \mathrm{~km}$ away and the explosion was heard $20 \mathrm{~km}$ from the crater. The eruption caused extensive damage and forced residents to flee down the mountain to safety. The physical infrastructure was damaged, including farmland and water installations. The direct losses amounted to 350 fatalities, 277 injured and 410,388 evacuated, as well as damaged infrastructure, houses, livestock and agricultural areas [35]. In monetary terms, the loss was reported as amounting to about USD 430 billion, of which $39 \%$ was related to settlements, $13 \%$ to water and irrigation, $43 \%$ to agriculture and $12 \%$ to industry and small to medium-sized enterprises. Tourism in Sleman Regency and the whole province of Yogyakarta was impacted by this event [36]. The most imperative determinant was the closing of Adi Sutjipto airport in Yogyakarta for two weeks and the consequent cancellation of 2467 flights.

\section{4) Kelud eruption (2014)}

In February 2014, Kelud volcano in East Java Province erupted. Volcanic material was spread up to $200 \mathrm{~km}$ from the crater, disturbing the social and economic activities of East Java Province and surrounding regencies; for instance, a loss of over USD 1.2 million was reported by the apple agro-tourism sector in Batu Regency, East Java. The eruption also disturbed flights due to the bad visibility caused by volcanic ash. Ground transport was also disrupted due to the 
blanket of ash making the roads slippery.

\section{5) Mentawai and Nias earthquake and tsunami (2010)}

This magnitude 7.7 earthquake occurred in October 2010 on the coast of Sumatra about $240 \mathrm{~km}$ west of Bengkulu. The United States Geological Survey reported the epicentre to be at a depth of $206 \mathrm{~km}$. The earthquake triggered a tsunami that destroyed the infrastructures in the district of Mentawai, West Sumatra. The total loss was reported to amount to about USD 1.3 million.

\section{6) Flooding in Jakarta (2013)}

Flooding poses a serious threat to the performance of Indonesia's tourism industry due to its impact on transport and travel activities. One of the areas that has been most impacted by flooding is Jakarta, because it is located in the coastal area [37] [38]. Furthermore, land-use change and urbanization over the past half century have exacerbated the problem [39]. The population of Jakarta increased from 2.7 million in 1960 to 9.9 million in 2014 [40]. In February 2007, a flood killed 58 people and the direct economic losses amounted to USD 453 million [38]. In 2013, flooding killed 47 people. Jakarta, the capital of Indonesia, has an important function in the tourism industry as a hub of international flights and tourist mobility flows.

\subsection{Human-Induced Disasters}

\section{1) Terrorist attacks, Bali (2002 and 2005)}

Terrorist attacks are now one of the major external threats to international travel and tourism, and the issue requires increased attention [41]. In October 2002, a nightclub in the Kuta Beach district of Bali was bombed. The explosion killed 190 people, including 88 Australian and 30 British tourists. Bali is one of the world's most popular international tourist destinations. Tourism plays a major role in the economic development and reinforcement of Bali, because the island lacks oil, natural gas and large-scale manufacturing industries, and agricultural yields are low. Moreover, this event threw an international spotlight on the Indonesian government, since the country's economy will to a certain extent be determined by the success of the government in arresting the perpetrators and eliminating terrorist cells. Furthermore, the action and lawsuit will convince other governments that security conditions have been improved and that therefore travel advisory warnings can be lifted [42]. Indonesia has suffered more terrorist attacks than any other country in Southeast Asia. One explosion happened in Kuta at 2002 and two occurred in Jimbaran at 2005; the latter explosions killed 23 people and injured 196.

\section{2) SARS outbreak (2003)}

SARS outbreaks are considered a human-induced disaster [43]. The first case of SARS was diagnosed in Guangdong Province, China. Due to SARS, the tourism and travel industry in China was severely disrupted. In Indonesia the number of tourists from China and surrounding areas dropped due to the warning given by their own governments. Many countries, including Indonesia, re- 
sponded to the SARS epidemic by issuing travel warnings. According to the World Health Organization [44], 774 of the 8096 people who contracted SARS died as a result. The Asian Development Bank estimated the cost to regional economies to be approximately USD 60 billion. Inter- and intra-regional tourism fell by $50 \%-70 \%$ and many businesses associated with travel and tourism collapsed [44]. In Indonesia, there were only two minor outbreaks of SARS and no deaths were reported. The vulnerability of tourism to disasters and crises was highlighted in this era.

\section{3) Political unrest/separatist movement and rebellion}

For 29 years Indonesia was threatened by a separatist movement, Gerakan Aceh Merdeka (GAM), in the Aceh region that was demanding independence. GAM received a lot of attention from both the Indonesian government and the national media. Almost every week the media reported a violent incident in Aceh. In 2005, a peace agreement was signed in Helsinki, Finland, between the Indonesian government and GAM. This led to a new phase of development in Aceh. In addition, the political instability that impacted the tourism development was also shown by the 1998 chaos, which forced President Soeharto from power after more than 30 years.

\section{4) Transport accidents}

Accidents are acknowledged to be a major cause of mortality and morbidity among travellers both in developing countries [45] and in Europe [46]. Five major aviation accidents have impacted the Indonesian tourism industry, namely those involving Lion Air (2004, 26 deaths), Mandala Airlines (2005, 141 deaths), Adam Air (2007, 102 deaths), Garuda Airline (2007, 22 deaths) and Air Asia (2014, 162 deaths). These events generated significant and continuing adverse publicity in both national and international media.

The image of accidents, destruction, instability and disease made the promotion of Indonesian tourism a challenging task for marketers. Not only natural disasters but also human-induced crises resulting from political tension and terrorism have impacted the performance of tourism activities and its pattern in contributing to the economic development of Indonesia. We studied both the direct impacts (Section 5.1) and the secondary impacts, namely the spillover effects (Section 5.2).

\section{Result and Analysis}

\subsection{Impact on the Performance of the Tourism Industry}

Indonesian tourism has benefited a lot from its neighbouring countries, especially Malaysia, Singapore and Australia, the top three countries for the Indonesian tourism market. In addition, the high and sustained growth of Asian economies has led to a shift away from the traditional European and US-based consumer market to inter-regional travel in Asia, especially between such countries as Indonesia, Japan, Singapore, Malaysia, Korea and China.

According to Statistics Indonesia, although the number of international tour- 
ist arrivals increased from five million in 2000 to 12 million in 2016, arrivals declined compared to the previous year by $11 \%$ in $1998,2 \%$ in $2002,11 \%$ in 2003 , $6 \%$ in 2005 and $3 \%$ in 2006 . The decline in 1998 was a result of political turmoil, as there were serious riots in several Indonesian cities where the majority of citizens demanded that Suharto step down as president. Then a $9 \%$ growth was recorded from 1998 to 2001 . However, in 2003 there was another fall, largely attributable to the SARS outbreak. Growth from 2003 to 2004 was about 19\%, but it dropped again in 2006 as a result of the terrorist attacks in Bali (2005) and the earthquake in Yogyakarta (2006). Following this, there was a steady increase in the number of international tourist arrivals until 2014. Figure 1 shows the fluctuation in the total number of inbound tourists arrivals in Indonesia.

The performance of the tourism industry can also be measured based on its impact on the economy, and especially on the tourism industry's share in the gross domestic product. The most income is generated from Malaysian tourists (about USD 1024 million in 2013), followed by Chinese tourists (about USD 754 million) and Australian tourists (about USD 750 million). According to Statistics Indonesia, from 1998 to 2015 the income from tourism increased by $182 \%$, namely from USD 4331 million to USD 12,225 million. However, the income fluctuated annually. Particularly in 2001 (B in Figure 2), 2003 (B in Figure 2), 2005 (C in Figure 2) and 2009 (D in Figure 2) the fall in income was significant overall pattern, however, is largely similar to the previous graph except in 2009, possibly influenced by the presidential election and the global economic crisis. Figure 2 shows the fluctuation in income from tourism between 1998 and 2015.

Unsurprisingly, the change in the number of inbound tourists arrivals was significantly related to changes in income, as the test of the relationship between

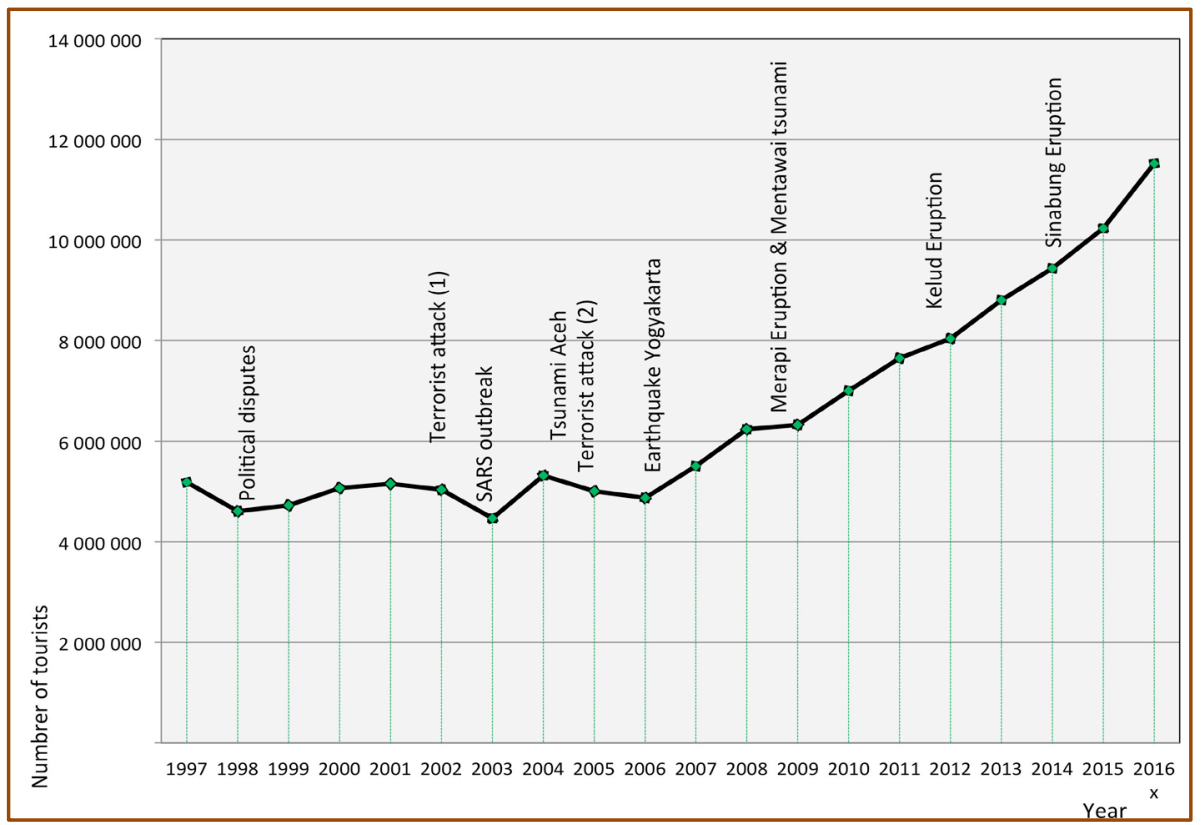

Figure 1. Fluctuation in the total number of tourists arriving at Indonesia's international airports in 1997-2016. Source: Statistics Indonesia, 2018 [47]. 


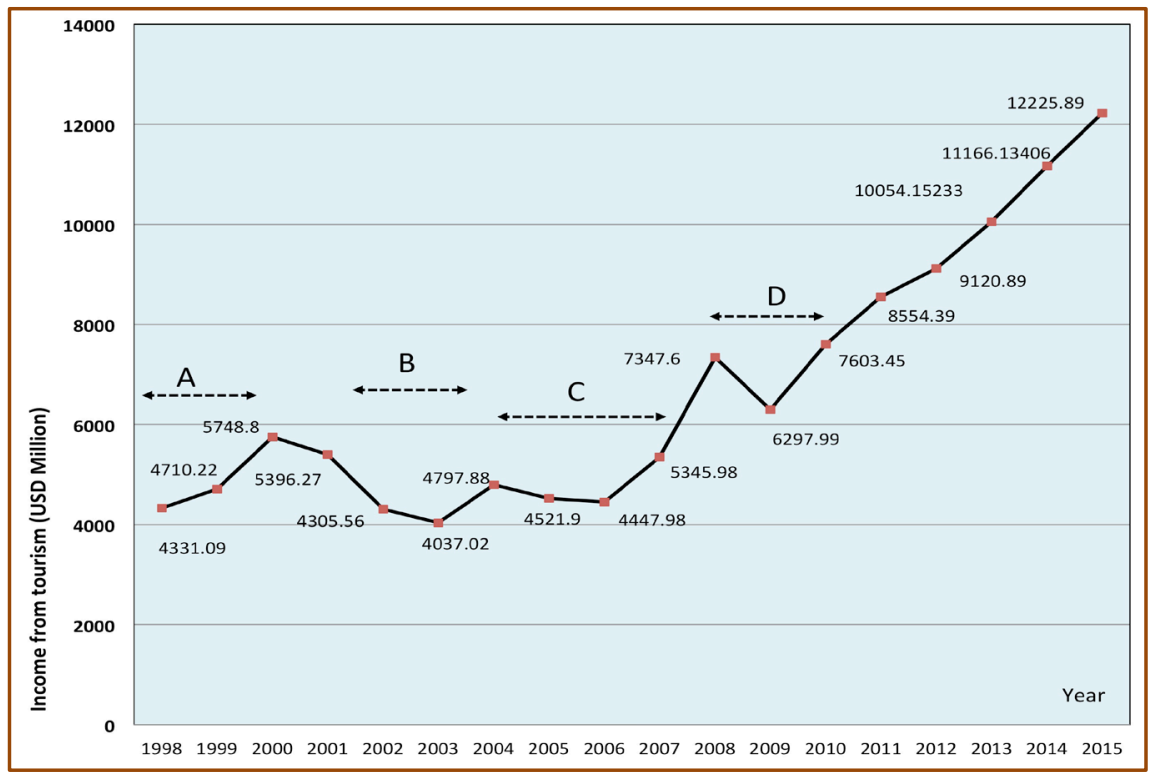

Figure 2. Fluctuation of income from tourism (1998-2015) in USD million. Source: Statistics Indonesia, 2018 [47].

inbound tourists arrivals and income resulted in a significant positive correlation $(\mathrm{R} 2=0.989 \mathrm{p}<0.001)$.

In the tourism industry, lodging is an important element in terms of visibility and it accounts for one third of tourists' direct spending [48] [49]. The number of rooms and beds in Indonesia increased from 2000 to 2016 at an average rate of $8 \%$ per year, as a result of the increasing number of hotels. Figure 3 shows the national hotel occupancy rate for hotels with and without a star rating between 1998 and 2016.

We thus found different impacts resulting from human-induced and natural disasters, with different intensities and consequences. In the case of the 2002 terrorist attacks, the statistical data revealed falls in all indicators mentioned above. In addition to the number of inbound tourists arrivals, the entire country's income from tourism was also impacted, as was the hotel occupancy rate. It is to these types of secondary impacts that we now turn.

\subsection{Destination's Spillover Effects}

When a disaster or crisis affects neighbouring regions in a positive or a negative way, it is labelled as a "spillover effect". The statistical data records in this paper reflect this effect. A positive spillover effect occurs when neighbouring regions benefit from a disaster in a certain area, because tourists tend to avoid the dangerous area and visit a destination that offers better safety and security [27]. Moreover, a negative spillover effect can occur for the same reason if people see that another part of the region may not be safe for tourism activities. This paper applies the Ritchie's definition of spillover effect which points the geographical perspective.

Table 3 shows the spillover effect of one disaster on other regions using the 


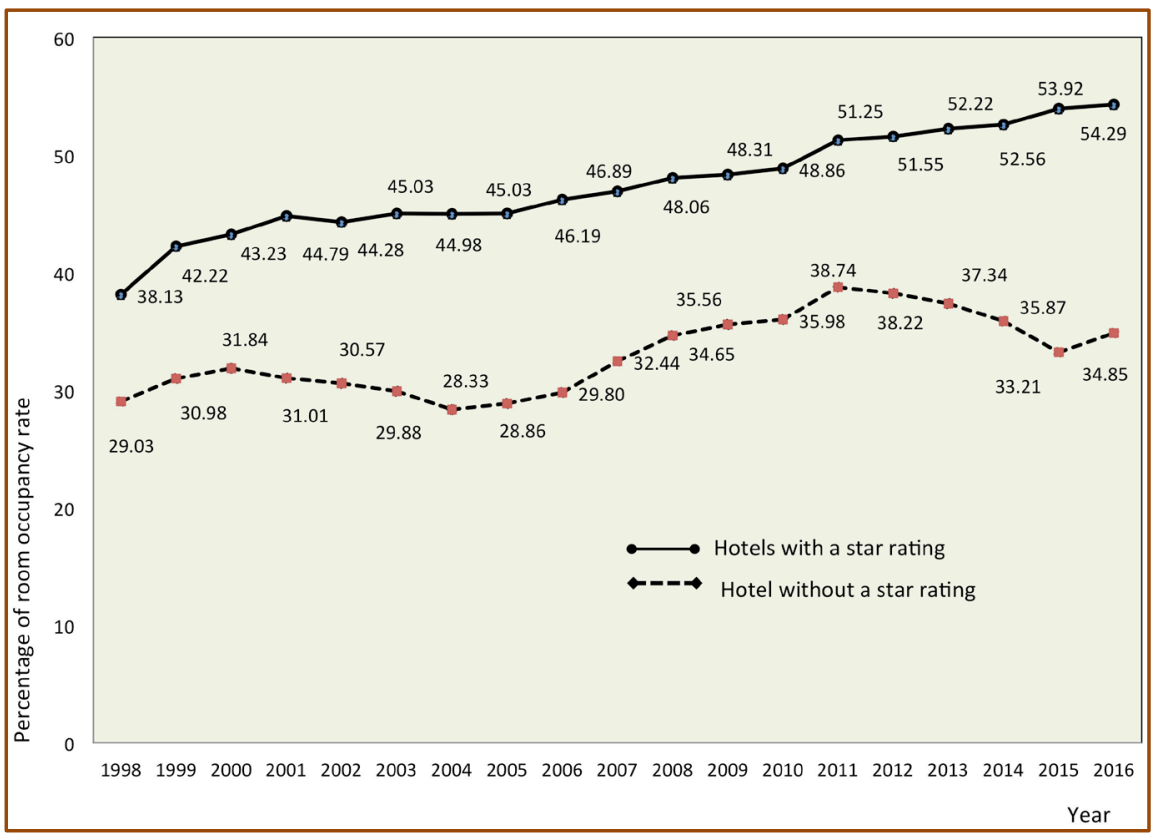

Figure 3. National hotel occupancy rate (1998-2016). Source: Statistics Indonesia, 2018 [47].

Table 3. Summary of the spillover effect on the performance of the tourism industry after five crisis events.

(a)

\begin{tabular}{cccccccc}
\hline \multirow{2}{*}{ Cases } & \multirow{2}{*}{ Year $(\mathrm{t})$} & \multicolumn{5}{c}{ Percentage of changes on Yogyakarta (\%) } \\
\cline { 3 - 8 } & & $(\mathrm{ROR})^{\mathrm{t}}$ & $(\mathrm{ROR})^{\mathrm{t}+1}$ & $(\Sigma \mathrm{IT})^{\mathrm{t}}$ & $(\Sigma \mathrm{IT})^{\mathrm{t}+1}$ & $(\mathrm{GDP})^{\mathrm{t}}$ & $(\mathrm{GDP})^{\mathrm{t}+1}$ \\
\hline Terrorist attack, Bali & 2002 & 1.5 & 12.35 & 7 & 20 & 1.9 & 259 \\
Tsunami, Aceh & 2004 & -1.7 & -5.6 & 8 & 0 & 5.8 & 5.0 \\
Terrorist attack, Bali & 2005 & -5.6 & 0.7 & 0 & -24 & 5.0 & 3.6 \\
Earthquake, Yogyakarta & 2006 & 0.7 & 5 & -24 & 32 & 3.6 & 5.1 \\
Merapi eruption, Yogyakarta & 2010 & -4.5 & 7.5 & 10 & 11 & 9.4 & 13.7 \\
\hline
\end{tabular}

(b)

\begin{tabular}{cccccccc}
\hline & \multirow{6}{*}{ Year $(\mathrm{t})$} & \multicolumn{5}{c}{ Percentage of changes on Bali (\%) } \\
\cline { 3 - 8 } & & $(\mathrm{ROR})^{\mathrm{t}}$ & $(\mathrm{ROR})^{\mathrm{t}+1}$ & $(\Sigma \mathrm{IT})^{\mathrm{t}}$ & $(\Sigma \mathrm{IT})^{\mathrm{t}+1}$ & $(\mathrm{GDP})^{\mathrm{t}}$ & $(\mathrm{GDP})^{\mathrm{t}+1}$ \\
\hline Terrorist attack, Bali & 2002 & -10.7 & -3.7 & -5.0 & -23 & -0.1 & 5.1 \\
Tsunami, Aceh & 2004 & -1.8 & -2.9 & 48 & -4 & 4.6 & 6.3 \\
Terrorist attack, Bali & 2005 & -2.9 & -5.4 & -4.0 & -11 & 6.3 & 5.1 \\
Earthquake, Yogyakarta & 2006 & -5.4 & 21.98 & -11 & 32 & 5.1 & 7.6 \\
Merapi eruption, Yogyakarta & 2010 & -1.9 & 0.7 & 8 & 10 & 6.4 & 8.7 \\
\hline
\end{tabular}

(c)

\begin{tabular}{cccccccc}
\hline & Year $(\mathrm{t})$ & \multicolumn{5}{c}{ Percentage of changes on Aceh (\%) } \\
\cline { 3 - 8 } & & $(\mathrm{ROR})^{\mathrm{t}}$ & $(\mathrm{ROR})^{\mathrm{t}+1}$ & $(\Sigma \mathrm{IT})^{\mathrm{t}}$ & $(\Sigma \mathrm{IT})^{\mathrm{t}+1}$ & $(\mathrm{GDP})^{\mathrm{t}}$ & $(\mathrm{GDP})^{\mathrm{t}+1}$ \\
\hline Terrorist attack, Bali & 2002 & 38.42 & -11.5 & -30 & -46 & 18 & 530 \\
Tsunami, Aceh & 2004 & 1.3 & -2.5 & -97.69 & 5218 & -3 & 12 \\
\hline
\end{tabular}


Continued

\begin{tabular}{cccccccc}
\hline Terrorist attack, Bali & 2005 & -2.5 & 22 & 5218 & 161 & 12 & 2 \\
Earthquake, Yogyakarta & 2006 & 22 & -7.4 & 161 & 20 & 2 & 2 \\
Merapi eruption, Yogyakarta & 2010 & -2.7 & -1.2 & 11 & 36 & 6 & 7 \\
\hline
\end{tabular}

Source: Authors' analysis.

indicators room occupancy rate of hotels with a star rating (ROR), number of international tourists ( $\Sigma \mathrm{IT}$ ) and regional gross domestic product of the hotel and restaurant sector (GDP). It also provides the data on the year of event $(t)$ and one year after the event $(t+1)$. A positive spillover effect can be seen in the case of the terrorist attack in Bali $(t=2002)$, when Bali suffered a $10.7 \%$ fall in room occupancy rate, Yogyakarta experienced a $1.5 \%$ increase and Aceh a $38.42 \%$ increase, the number of tourists visiting Bali dropped by $5 \%$, and the number visiting Yogyakarta increased by $5 \%$. In the case of the earthquake in Yogyakarta, Yogyakarta experienced a 24\% fall in the number of tourists while Aceh saw a $161 \%$ increase. A negative spillover effect can also be seen from the table: when Yogyakarta had an earthquake, the number of tourists visiting Bali fell by $11 \%$.

Examining the GDP of the trade, hotel and restaurant sectors at the provincial level reveals an interesting detail. The terrorist attack in 2002 and the tsunami in Aceh only impacted the GDP of the affected province, and did not affect the growth of GDP in other regions. The GDP of the trade, hotel and restaurant sectors in Bali fell $0.1 \%$ after the terrorist attack in 2002, and after the tsunami the GDP of the trade hotel, and restaurant sectors in Aceh fell by 3\%. Hence, other regions seem to experience a positive spillover effect on their GDP resulting from increased products and services in hotels and restaurants.

Figures 4-7 show the changes in the number of tourists arriving at the four main airports (i.e. Soekarno Hatta, Denpasar, Kualanamu and Batam Island). For example, in 1998 and 1999, the number of inbound tourists arriving at Jakarta airport dropped significantly (by 39\% in 1998 and 7\% in 1999). However, at the same time Batam airport reported a 5\% - 6\% increase in the number of foreign tourists compared to the previous year. This supports the hypothesis that tourists tend to avoid the possibility of conflicts and problems (as mentioned, there were serious riots in Jakarta in 1998-99). Similar impacts of political uncertainty can be seen in the data for 2009, when the presidential election was held: there was a $3 \%$ drop in the number of inbound tourist entering via Jakarta and Batam, whereas numbers increased at Kualanamu and Denpasar. The other case of spillover concerns the post-terrorist attack period in Bali: tourists tended to avoid landing in Bali, Jakarta, Medan and other airports, whereas Batam Island airport saw a $17 \%$ increase in the number of inbound tourists arrivals, as shown in Figure 5.

\subsection{Government Responses to Tourism Crises}

The Indonesian government started to pay attention to tourism development in 


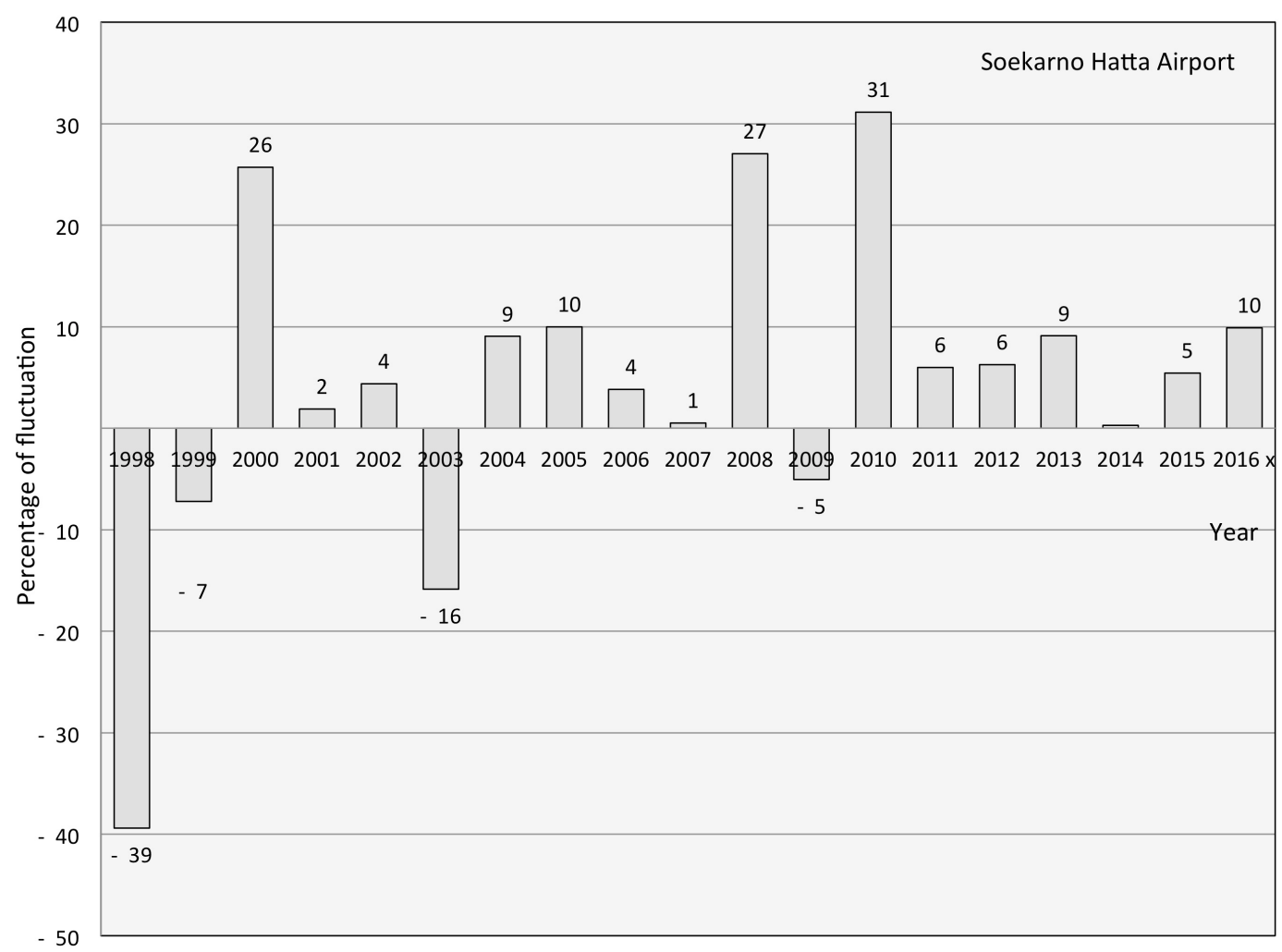

Figure 4. Changes in number of inbound tourists entering at Soekarno Hatta, Jakarta airport 1997-2016.

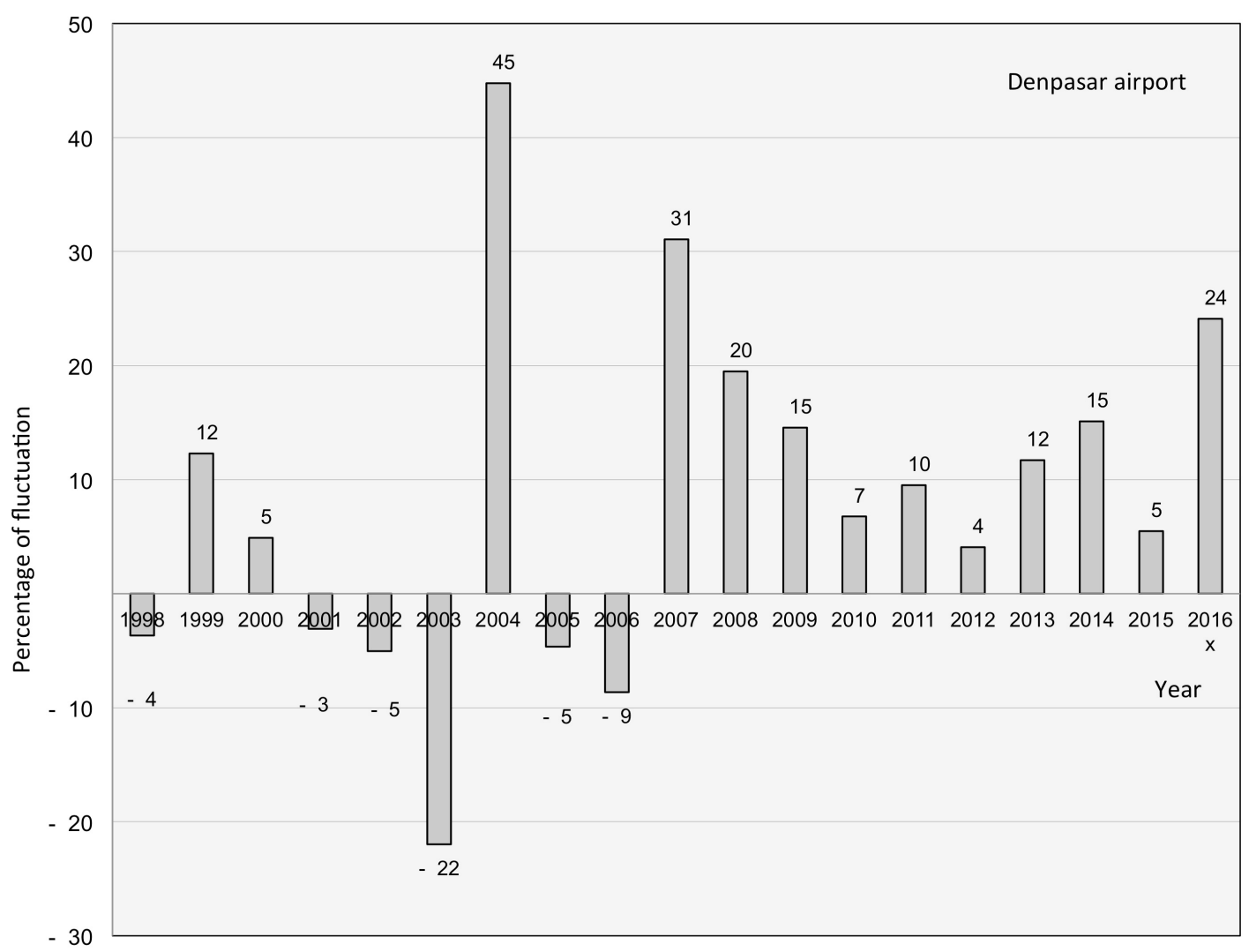

Figure 5. Changes in number of inbound tourists at Denpasar Bali airport 1997-2016. 


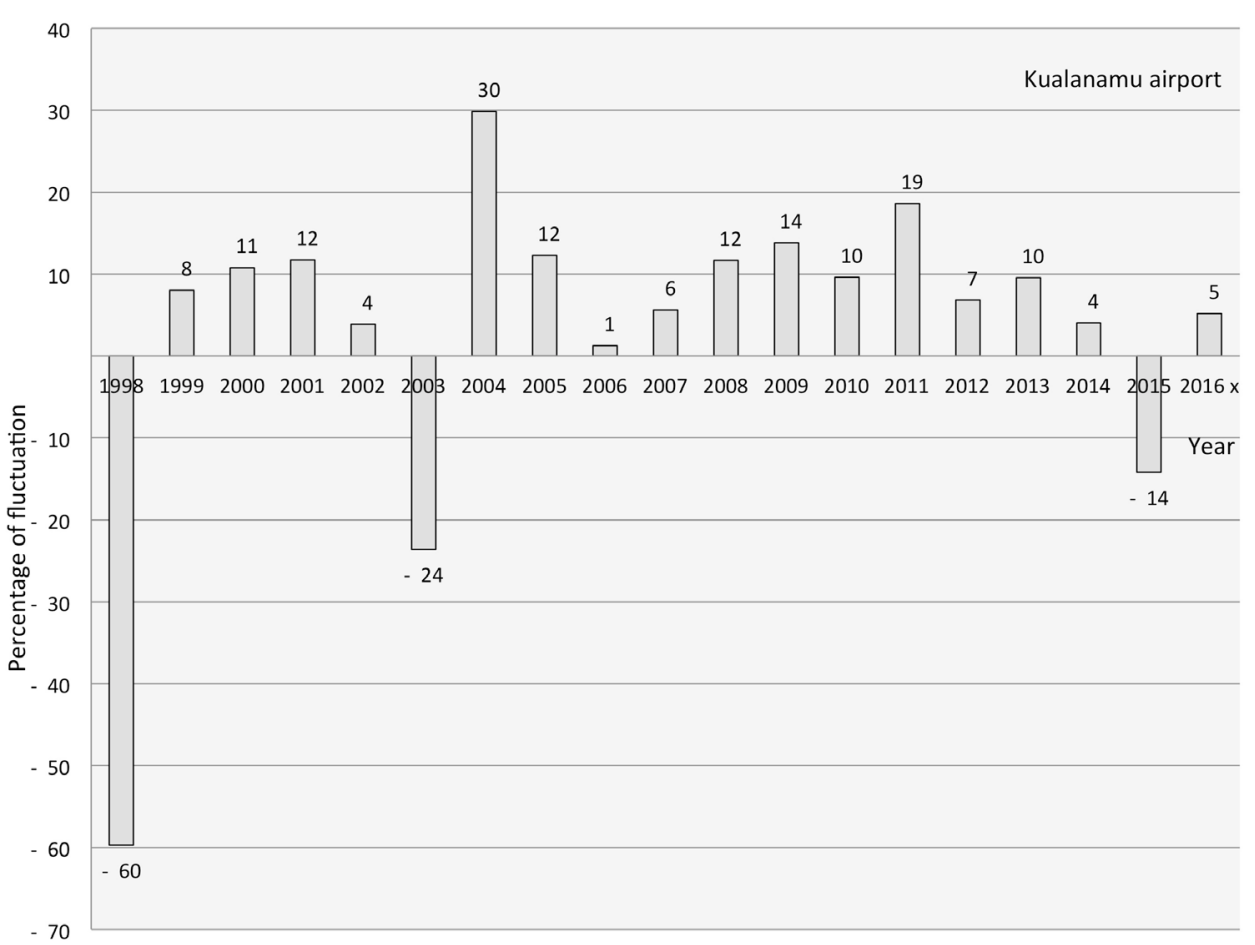

Figure 6. Changes in number of inbound tourists at Kualanamu, Medan airport 1997-2016.

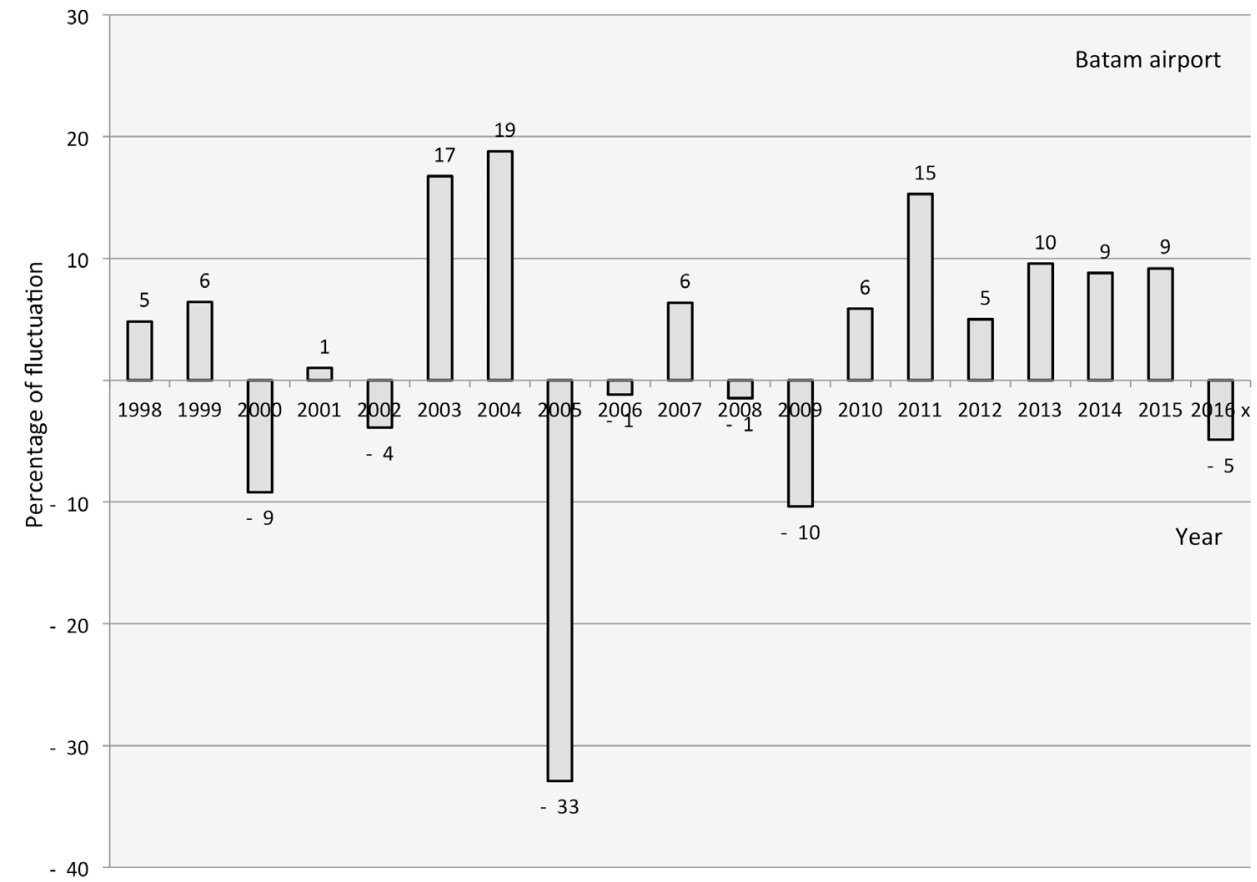

Figure 7. Changes in number of inbound tourists at Batam Riau Island airport 1997-2016.

1969 through the establishment of the Directorate General for Ministry of Transportation. This ministry developed a five-yearly development plan (PELITA/Pembangunan Lima Tahun). The aim was to increase the number of tourist arrivals by $10 \%-13 \%$ per year from 1967 to 1999 . However, in 1998 the 
economic crisis influenced the political stability, which led to the decreasing performance of the tourism industry. After the economic crisis, the reformation era was characterized by political transformation, namely from centralization to decentralization. In this era, many regions wanted to develop tourism as their source of income; as a result, tourism competition between regions has increased [50].

At the regional level, regional governments have been instructed to do their regional tourism planning and development under the umbrella of the Ministry of Culture and Tourism. The aim is to build cooperation between different levels of government, business sectors and communities. The local government should plan certain aspects, namely tourists, transport, tourism products, services and facilities, and tourism destination information. Some national programmes have been launched, such as the National Strategic Tourism Area and the Master Plan for Acceleration and Expansion of Indonesia's Economic Development 2011-2025. These two programmes focus on increasing the number of tourists, which increases the national or regional income, while overlooking the aspect of crisis management.

The government's response to the impact of disasters on tourism shows a general lack of preparatory actions; instead, it is based on responsive actions. The Disaster Board focuses on keeping people safe during a disaster rather than preparing for a worst-case scenario by developing a comprehensive planning and recovery strategy. The Tourism Board at the provincial level has also shown poor planning for disaster mitigation in tourist destinations.

\section{Discussion}

\subsection{Multi-Layered Disasters and Spillover Effects}

The results of the analysis show that each disaster in Indonesia, whether natural or human-induced, is on a different scale and has a different impact on the performance of the tourism industry. However, this research also suggests that double disaster in the same time may impact differently depend on the location and scale. Although it is possible that there are other factors of importance in the complex system of tourism, i.e. the dynamic of the source of the tourists market, there are some general remarks we can make on the basis of our findings. First, during the past two decades, disasters have usually had a multi-layered character that impacted the performance of the tourism according to the scale of destruction, the location of the disaster and the type of disaster (human-induced vs. nature-induced). These factors influence the magnitude of the impact on the tourism industry and also the recovery speed (i.e. how long it takes to return to a "normal" state).

Second, secondary impacts (i.e. spillover effects) are indicated by the benefits gained by other provinces due to the decreased performance of the tourism industry in an area affected by a disaster. In the whole nation, spillover effects may not be clearly seen, but data on arrivals at each international airport reveal an 
interesting fluctuation. This fluctuation at the provincial level shows that spillover effects have occurred due to disruptions in other tourist destinations.

\subsection{Towards a Structural Approach in Policy Responses}

This paper proposes a structural approach in policy responses to disasters in the tourism industry. The challenges of recovery in tourism post-disaster that can be observed are the lack of a clear definition of crisis vs. disaster, poor determination of actor responsibilities, and a general lack of mitigation, preparation and recovery strategies to comprehensively deal with the impact. A structural approach includes the implementation of programmes to change the conditions in which people live or the community processes that catalyse social and political change [51]. The aim of such policies is to change the conditions in all economic, social, political, organizational, environmental, and human capital aspects related to tourism development and disasters.

A structural approach policy response is important for the tourism industry during crises, because the programmes that have been conducted by the Indonesian tourism stakeholders did not take into account the automatic stabilizers that dampen the fluctuation in income from tourism. The programmes were sporadic, fragmented and reactive, and lacked a shared objective for the whole nation. Moreover, this study found that the policy does not play a role in changing rules and procedures to facilitate the acceleration of investment in the tourism industry to make it safer and ready for disasters, because it is only implemented for particular sectors.

In a structural policy approach, disasters should not damage the drivers of the long-term growth of tourism, but should be used as a springboard to accelerate a structural shift towards a stronger, more resilient and sustainable tourism development. In mainstream disaster preparation, the implementation of a structural policy approach must recognize that context matters, namely that each disaster requires its own, individual coping strategy. To implement a structural policy approach, the social, political, economic and environmental factors influencing both vulnerability and risk must be identified.

First, the economic condition of the country affects the speed of recovery. Bankruptcies and business failures have been observed post-disaster in the tourism industry. Disaster can have a detrimental effect on the creation of new, innovative tourism business when access to financing dries up. Financial support increases the possibility to reconstruct and build the recovery programme in image building as well as infrastructure rebuilding, for example, financial support for small or medium-sized enterprises, support for hotel and restaurant recovery, and destination promotion. In one hit, tourism can collapse without financial support from other agencies. In this respect, the government plays a pivotal role in terms of both direct financial package loans and a policy incentive for financial institutions (e.g. banks) to support the recovery.

Second, in the political context, a structural approach policy opens space for 
the political aspect to also work for recovery. Spillover effects that happen after a disaster have two sides to them, one positive and one negative. If the spillover effect occurs in another province, the benefit of tourism income remains in the country, but if the spillover effect occurs abroad, it reduces the revenue from tourism and other countries benefit. This is illustrated by the case of the 2002 Bali bombings: Thailand and New Zealand became more popular among Australian tourists as an alternative to Bali. Therefore, strengthening the communication between countries is important to build stability for recovery post-disaster.

Third, social and political stability in the country may increase the speed of recovery. Recovery will be achieved if the situation is conducive to innovation. The terrorist attacks in 2002 and 2005 made tourists stay away from Bali. Moreover, it was not the renovation of hotels and restaurants in Bali that made tourism return to normal, but news in the media about how the Indonesian police were working to catch the perpetrators. Tourism recovery required the strengthening of structural policies for anti-terrorism (i.e. anti-terrorism law UU No.15/2003), rather than short-term relief, such as promoting alternative destinations or offering discounts.

Fourth, as regards policy and organizational structure, a disaster may provide an opportunity to reflect on the mission and vision of the policy and to reform the policy to make it more comprehensive, structured and inclusive. Disaster raises hard new questions and provides options for all stakeholders; however, it also provides an opportunity to strengthen the medium- and long-term potential of the tourism industry. The government can introduce new policy measures that stimulate innovation to tackle the tourism downturn. Some policies may increase the cost in the short term, but most are likely to create benefit in the longer term.

Finally, the aspect of human resources and development requires attention in order to cope with the tourism crisis resulting from the disaster event. In the event of a long, large-scale disaster, many companies may lay off employees, which leads to a high number of unemployed-which is another social and economic problem that triggers yet another problem. Education and training during a crisis is important as part of a structural policy in tourism that can help displaced workers find new job opportunities and can thus support the process of restructuring.

\section{Conclusions}

Increasing numbers of disasters and crises have stimulated research on the impact of such events on the performance of the tourism industry. Nevertheless, studies on the impact of disasters on the tourism industry have presented disasters as single events over a short period of time. Moreover, the majority of the research has neglected the mapping of events over time. There is a need to address in a more systematic way the complex challenges and spillover effects of crises on other destinations, and to compare disaster impacts on the perfor- 
mance of the tourism industry.

The present research assessed the impact of different human-induced and natural disasters on the performance of the tourism industry in Indonesia over time (1998-2016) using the variables inbound tourists arrivals, income from tourism activities and hotel occupancy rates. Using secondary data, this paper has provided a better understanding of the impact of disasters and crises on the tourism industry as a whole, as well as a comparison between natural disasters and human-induced disasters, and between regions in affected areas.

Two reflections can be drawn from this study's results. First, human-induced disasters have a more negative impact on the destination and the recovery process compared to natural disasters. In contrast, some natural disasters attract media attention, leading to new tourism development in the affected area. What happened in Bali in 2002 was the most destructive event for tourism in both Bali itself and at the national level. Compared to natural disaster events, such as tsunamis and earthquakes, this human-induced disaster presented a significant challenge, as it was difficult to convey a positive image of Bali after the attacks [52]. The results support Sonmez [53] (1998: 417), who wrote, "The threat of danger that accompanies terrorism or political turmoil tends to intimidate potential tourists more severely than any natural or human-caused disaster". Buigut et al. [54] also studied the impact of terrorism and found that it significantly decreases tourism demand. Moreover, Drakos and Kutan [23] found that terrorism has the most immediate and strongest effects on tourism.

Second, disasters and crises impact neighbouring regions in both positive and negative ways. The statistical data presented in this paper revealed positive spillover effects when neighbouring provinces benefitted from disasters in another area, because tourists tend to avoid dangerous areas and visit alternative destinations that are safer and more secure. This finding supports the conclusions of previous research that only studied spillover effects in cases of single disasters; for instance, research by Yang and Wong [22] confirmed the existence of spillover effects in tourism flows for both foreign and domestic tourists after the SARS outbreak, as well as a statement from Ritchie, Crotts, Zehrer, \& Volsky [27] on the existence of spillover effects in the accommodation sector.

Finally, tourism is a complex system that is strongly related to external and internal factors, implying that a single system approach fails to understand the multi-layered nature of the impacts. By understanding tourism from a complex systems approach, national destination management may provide alternatives to anticipate spillover effects when disasters happen in a certain area. The government could take a leading role in defining and implementing programmes aimed at structural change in affected regions. This paper proposes a structural approach in policy responses that covers all dimensions of tourism and disaster recovery.

Furthermore, the research can be followed by the future research such as econometric analysis in each event and the analysis of governmental responses to 
such disaster. The two studies appear to be an important area that requires further research.

\section{Acknowledgements}

This research has been supported by Indonesia Endowment Fund for Education (LPDP).

\section{Conflicts of Interest}

The authors declare no conflicts of interest regarding the publication of this paper.

\section{References}

[1] Page, S., Yeoman, I., Munro, C., Connell, J. and Walker, L. (2006) A Case Study of Best Practice-Visit Scotland's Prepared Response to an Influenza Pandemic. Tourism Management, 27, 361-393. https://doi.org/10.1016/j.tourman.2006.01.001

[2] Scott, N. and Laws, E. (2006) Tourism Crises and Disasters: Enhancing Understanding of System Effects. Journal of Travel \& Tourism Marketing, 19, 149-158. https://doi.org/10.1300/J073v19n02_12

[3] Faulkner, B. (2001) Towards a Framework for Tourism Disaster Management. Tourism Management, 22, 135-147. https://doi.org/10.1016/S0261-5177(00)00048-0

[4] Higgins, B.A. (2005) The Storms of Summer: Lessons Learned in the Aftermath of the Hurricanes of '04. Cornell Hotel and Restaurant Administration Quarterly, 46, 40-46. https://doi.org/10.1177/0010880404272444

[5] Calgaro, E. and Lloyd, K. (2008) Sun, Sea, sand and Tsunami: Examining Disaster Vulnerability in the Tourism Community of Khao Lak, Thailand. Singapore Journal of Tropical Geography, 29, 288-306. https://doi.org/10.1111/j.1467-9493.2008.00335.x

[6] Cheung, C. and Law, R. (2006) How Can Hotel Guests Be Protected during the Occurrence of a Tsunami? Asia Pacific Journal of Tourism Research, 11, 289-295. https://doi.org/10.1080/10941660600753331

[7] Huang, J. and Min, J.C. (2002) Earthquake Devastation and Recovery in Tourism: The Taiwan Case. Tourism Management, 23, 145-154. https://doi.org/10.1016/S0261-5177(01)00051-6

[8] Carlino, S., Somma, R. and Mayberry, G. (2008) Volcanic Risk Perception of Young People in the Urban Areas of Vesuvius: Comparisons with Other Volcanic Areas and Implications for Emergency Management. Journal of Volcanology and Geothermal Research, 172, 229-243. https://doi.org/10.1016/j.jvolgeores.2007.12.010

[9] Armstrong, E.K. and Ritchie, B.W. (2008) The Heart Recovery Marketing Campaign: Destination Recovery after a Major Bushfire in Australia's National Capital. Journal of Travel \& Tourism Marketing, 23, 175-189. https://doi.org/10.1300/J073v23n02_14

[10] Rodway-Dyer, S. and Shaw, G. (2005) The Effects of the Foot-and-Mouth Outbreak on Visitor Behaviour: The Case of Dartmoor National Park, South-West England. Journal of Sustainable Tourism, 13, 63-81. https://doi.org/10.1080/17501220508668473

[11] Au, A.K., Ramasamy, B. and Yeung, M.C. (2005) The Effects of SARS on the Hong Kong Tourism Industry: An Empirical Evaluation. Asia Pacific Journal of Tourism 
Research, 10, 85-95. https://doi.org/10.1080/1094166042000330236

[12] Kasperson, R.E., Golding, D. and Tuler, S. (1992) Social Distrust as a Factor in Siting Hazardous Facilities and Communicating Risks. Journal of Social Issues, 48, 161-187. https://doi.org/10.1111/j.1540-4560.1992.tb01950.x

[13] Laws, E., Prideaux, and Chon, K. (2007) Crisis Management in Tourism: Challenges for Managers and Researchers. In: Laws, E., Prideaux, B. and, Chon, K., Eds., Crisis Management in Tourism, CABI, Oxfordshire, 1-392.

[14] Scott, N., Laws, E. and Prideaux, B. (2007) Tourism Crises and Marketing Recovery Strategy. Journal of Travel and Tourism Marketing, 23, 1-13. https://doi.org/10.1300/J073v23n02_01

[15] Hall, C.M. (2008) Tourism Planning: Policies, Processes and Relationships. Pearson Education, London.

[16] Faulkner, B. and Valerio, P. (2003) An Integrative Approach to Tourism Demand Forecasting. Progressing Tourism Research, 9, 166. https://doi.org/10.21832/9781873150498-013

[17] Baggio, R. (2013) Studying Complex Tourism Systems: A Novel Approach Based on Networks Derived from a Time Series. arXiv:1302.5909

[18] Haugland, S.A., Ness, H., Grønseth, B. and Aarstad, J. (2011) Development of Tourism Destinations: An Integrated Multilevel Perspective. Annals of Tourism Research, 38, 268-290. https://doi.org/10.1016/j.annals.2010.08.008

[19] Beeton, S. (2001) Horseback Tourism in Victoria, Australia: Cooperative, Proactive Crisis Management. Current Issues in Tourism, 4, 422-439.

[20] Coombs, W.T. (2014) Ongoing Crisis Communication: Planning, Managing, and Responding. Sage Publications, Thousand Oaks.

[21] Parsons, W. (1996) Crisis Management. Career Development International, 1, 26-28. https://doi.org/10.1108/13620439610130614

[22] Yang, Y. and Wong, K.K. (2012) A Spatial Econometric Approach to Model Spillover Effects in Tourism Flows. Journal of Travel Research, 51, 768-778. https://doi.org/10.1177/0047287512437855

[23] Drakos, K. and Kutan, A.M. (2003) Regional Effects of Terrorism on Tourism in Three Mediterranean Countries. Journal of Conflict Resolution, 47, 621-641. https://doi.org/10.1177/0022002703258198

[24] Gooroochurn, N. and Hanley, A. (2005) Spillover Effects in Long Haul Visitors between Two Regions. Regional Studies, 39, 727-738. https://doi.org/10.1080/00343400500213606

[25] Neumayer, E. (2004) The Impact of Political Violence on Tourism: Dynamic Cross-National Estimation. Journal of Conflict Resolution, 48, 259-281. https://doi.org/10.1177/0022002703262358

[26] Pforr, C. (2009) Crisis Management in Tourism: A Review of the Emergent Literature. In: Crisis Management in the Tourism Industry. Beating the Odds, Ashgate, Farnham, 37-52.

[27] Ritchie, B.W., Crotts, J.C., Zehrer, A. and Volsky, G.T. (2013) Understanding the Effects of a Tourism Crisis: The Impact of the BP Oil Spill on Regional Lodging Demand. Journal of Travel Research, 53, 12-25. https://doi.org/10.1177/0047287513482775

[28] Gil-Pareja, S., Llorca-Vivero, R. and Martínez-Serrano, J.A. (2007) The Impact of Embassies and Consulates on Tourism. Tourism Management, 28, 355-360. https://doi.org/10.1016/j.tourman.2006.04.016 
[29] Khadaroo, J. and Seetanah, B. (2007) Transport Infrastructure and Tourism Development. Annals of Tourism Research, 34, 1021-1032. https://doi.org/10.1016/j.annals.2007.05.010

[30] Coshall, J.T. (2000) Spectral Analysis of Overseas Tourists' Expenditures in the United Kingdom. Journal of Travel Research, 38, 292-298. https://doi.org/10.1177/004728750003800312

[31] Dupeyras, A. and MacCallum, N. (2013) Indicators for Measuring Competitiveness in Tourism: A Guidance Document. OECD Tourism Papers, 2013/02, OECD Publishing, Paris.

[32] World Economic Forum (2017) The Travel and Tourism Competitiveness Report 2017. https://www.weforum.org/reports/the-travel-tourism-competitiveness-report-2017

[33] Church, R.M. (2002) The Effective Use of Secondary Data. Learning and Motivation, 33, 32-45. https://doi.org/10.1006/lmot.2001.1098

[34] Saunders, M., Lewis, P. and Thornhill, A. (2000) Collecting Primary Data through Observation. In: Saunders, M.N.K., Lewis, P. and Thornhill, A., Eds., Research Methods for Business Students, Financial Times/Prentice Hall, Harlow, 218-236.

[35] Mei, E.T.W. and Lavigne, F. (2012) Influence of the Institutional and Socio-Economic Context for Responding to Disasters: Case Study of the 1994 and 2006 Eruptions of the Merapi Volcano, Indonesia. Geological Society, London, Special Publications, 361, 171-186. https://doi.org/10.1144/SP361.14

[36] Rindrasih, E. (2018) Under the Volcano: Responses of a Community-Based Tourism Village to the 2010 Eruption of Mount Merapi, Indonesia. Sustainability, 10, 1620. https://doi.org/10.3390/su10051620

[37] Caljouw, M., Nas, P.J. and Pratiwo, M. (2005) Flooding in Jakarta: Towards a Blue City with Improved Water Management. Journal of the Humanities and Social Sciences of Southeast Asia, 161, 454-484.

[38] Steinberg, F. (2007) Jakarta: Environmental Problems and Sustainability. Habitat International, 31, 354-365. https://doi.org/10.1016/j.habitatint.2007.06.002

[39] Firman, T. (2009) The Continuity and Change in Mega-Urbanization in Indonesia: A Survey of Jakarta-Bandung Region (JBR) Development. Habitat International, 33, 327-339. https://doi.org/10.1016/j.habitatint.2008.08.005

[40] Statistics Indonesia (2016) Jakarta in Figures. Statistic Agency of Indonesia, Jakarta.

[41] O'Connor, N., Stafford, M.R. and Gallagher, G. (2008) The Impact of Global Terrorism on Ireland's Tourism Industry: An Industry Perspective. Tourism and Hospitality Research, 8, 351-363. https://doi.org/10.1057/thr.2008.29

[42] Prideaux, B., Laws, E. and Faulkner, B. (2003) Events in Indonesia: Exploring the Limits to Formal Tourism Trends Forecasting Methods in Complex Crisis Situations. Tourism Management, 24, 475-487. https://doi.org/10.1016/S0261-5177(02)00115-2

[43] Jennex, M. (2012) Managing Crises and Disasters with Emerging Technologies. Advancements IGI Global. https://doi.org/10.4018/978-1-4666-0167-3

[44] World Health Organization (2005) Global Health Improvement and WHO: Shaping the Future. http://www.who.int/whr/2003/media_centre/lee_article/en/index2.html

[45] Stewart, B.T., Yankson, I.K., Afukaar, F., Medina, M.C.H., Cuong, P.V. and Mock, C. (2016) Road Traffic and Other Unintentional Injuries among Travelers to Developing Countries. Medical Clinics, 100, 331-343.

[46] EU Report (2005) Scope and Patterns of Tourist Injuries in the European Union. 
International Journal of Injury Control and Safety Promotion, 12, 57-61. https://doi.org/10.1080/15660970412331289715

[47] Statistics Indonesia (2018) Statistic Dasar Pariwisata. https://www.bps.go.id/subject/16/pariwisata.html\#subjek3

[48] Davidson, M.C., Timo, N. and Wang, Y. (2010) How Much Does Labour Turnover Cost? A Case Study of Australian Four- and Five-Star Hotels. International Journal of Contemporary Hospitality Management, 22, 451-466. https://doi.org/10.1108/09596111011042686

[49] Sharpley, R. (2000) The Influence of the Accommodation Sector on Tourism Development: Lessons from Cyprus. International Journal of Hospitality Management, 19, 275-293. https://doi.org/10.1016/S0278-4319(00)00021-9

[50] Rindrasih, E. (2015) Tourism and Disaster: The Review of Government Policy toward the Impact of Natural Disaster on Tourism Industry Performance. ASEAN Journal on Hospitality and Tourism, 14, 24-34.

[51] Gupta, G.R., Parkhurst, J.O., Ogden, J.A., Aggleton, P. and Mahal, A. (2008) Structural Approaches to HIV Prevention. The Lancet, 372, 764-775. https://doi.org/10.1016/S0140-6736(08)60887-9

[52] Henderson, J.C. (2003) Terrorism and Tourism: Managing the Consequences of the Bali Bombings. Journal of Travel \& Tourism Marketing, 15, 41-58. https://doi.org/10.1300/J073v15n01_03

[53] Sönmez, S.F. and Graefe, A.R. (1998) Determining Future Travel Behavior from Past Travel Experience and Perceptions of Risk and Safety. Journal of Travel Research, 37, 171-177. https://doi.org/10.1177/004728759803700209

[54] Buigut, S., Braendle, U. and Sajeewani, D. (2017) Terrorism and Travel Advisory Effects on International Tourism. Asia Pacific Journal of Tourism Research, 22, 991-1004. https://doi.org/10.1080/10941665.2017.1359193 